\title{
Pengaruh Konsentrasi Sukrosa Terhadap Karakteristik Minuman Sari Buah Sirsak (Annona muricata Linn) Terfermentasi Dengan Isolat Lactobacillus sp. F213
}

\author{
The Effect of Sucrose Concentration on the Characteristics of Fermented Soursop (Annona \\ muricata Linn) Juice with Lactobacillus sp. F213
}

\author{
A.A. Gd. Tryadi Pradipta*, Komang Ayu Nocianitri, I Dewa Gde Mayun Permana \\ Program Studi Ilmu dan Teknologi Pangan, Fakultas Teknologi Pertanian, \\ Universitas Udayana, Jl. Raya Kampus Unud, Jimbaran, Kuta Selatan, Badung-Bali \\ *Email: yomi.pradipt@gmail.com
}

\begin{abstract}
Lactobacillus sp. F213 (LbF213) is a lactic acid bacteria (LAB) that has the potential as a probiotic because it can provide health effects for those who consume it, so it is necessary to make efforts to increase the application of LbF213 in the field of food processing. This study aims to determine the effect of sucrose concentration on the characteristics of fermented soursop juice with LbF213 isolates and get the right concentration of sucrose to produce fermented soursop juice with the best characteristics. The experimental design used was Randomized Block Design with sucrose treatment of $0 \%, 3 \%, 6 \%, 9 \%$, and $12 \%$. Each treatment was repeated 3 times to obtain 15 experimental units. LAB total was analyzed descriptively and the other variables were analyzed by ANOVA and if there was an influence between treatments continued with Duncan test. The results showed that sucrose treatment affected total sugar, taste (hedonic), sour taste and sweet taste (score), overall acceptance (hedonic). The 6\% sucrose treatment produced the best fermented soursop juice with a total LAB $1,27 \times 10^{10} \mathrm{cfu} / \mathrm{ml}$, total sugar $12.91 \%$, total acid $1.57 \%$, $\mathrm{pH} 3.83$, color and aroma rather liked, with a slight taste sour and rather sweet liked, and overall acceptance liked.
\end{abstract}

Keywords: Fruit juice, Lactobacillus sp. F213, sucrose concentration

\section{PENDAHULUAN}

Salah satu produk pangan fungsional yang beredar luas di pasaran adalah minuman probiotik. Minuman probiotik adalah minuman yang mengandung bakteri seperti bakteri asam laktat (BAL) yang menguntungkan bagi saluran pencernaan karena dapat meningkatkan keseimbangan mikroflora usus dan mampu bertahan hidup dalam keasaman lambung sehingga dapat menempati usus dalam kuantitas yang cukup besar (Rizal et al., 2016). Minuman probiotik umumnya menggunakan bahan utama berupa susu, namun beberapa tahun terakhir telah dikembangkan minuman probiotik berbahan dasar sari buah. Buah dapat dijadikan alternatif pengganti susu karena buah mengandung nutrisi seperti gula dan protein yang diperlukan untuk pertumbuhan BAL dan memiliki nilai ekonomis tinggi. Minuman probiotik dari buah yang sudah diteliti sebelumnya adalah penelitian sari buah nanas (Rizal et al., 2016), sari buah tomat (Harahap et al., 2018), sari buah jambu biji (Nurainy et al., 2018), dan sari buah sirsak (Rini, 2019). Sirsak (Annona muricata Linn) merupakan 
salah satu buah yang dapat dijadikan minuman probiotik sari buah. Sirsak merupakan media yang bagus untuk pertumbuhan BAL karena mengandung kadar gula sekitar 13,5 g dan vitamin C yang cukup tinggi, yaitu sekitar 20 mg per 100 $\mathrm{g}$ daging buah.

Penelitian Rini (2019) tentang buah sirsak yaitu meneliti viabilitas Lactobacillus sp. F213 pada minuman probiotik sari buah sirsak selama penyimpanan dingin. Hasil menunjukkan viabilitas Lactobacillus sp. F213 stabil pada buah sirsak, yaitu jumlah populasi BAL pada kisaran $1,55 \times 10^{6} \mathrm{cfu} / \mathrm{ml}$ sampai dengan $4,30 \times 10^{5} \mathrm{cfu} / \mathrm{ml}$ hingga penyimpanan hari ke-12. Potensi yang dimiliki buah sirsak tersebut dapat dikembangkan dengan melakukan fermentasi minuman sari buah sirsak agar memperoleh karakteristik yang lebih baik seperti jumlah populasi BAL yang mencukupi dalam minuman probiotik yaitu $10^{6}$ $10^{8} \mathrm{cfu} / \mathrm{ml}$ dan nilai sensoris yang disukai.

Lactobacillus sp. F213 (LbF213) adalah salah satu jenis BAL yang telah diteliti 11 tahun terakhir dan memiliki efek kesehatan ketika dikonsumsi dalam jumlah yang tepat. LbF213 diisolasi dari feses bayi sehat, yang telah terbukti berperan sebagai probiotik karena tahan terhadap $\mathrm{pH}$ rendah, garam empedu, enzim pencernaan, mampu melakukan agregasi, menempel, dan berkolonisasi di usus, serta berinteraksi melawan Escherichia coli (Sujaya, 2010). Penelitian Sujaya et al., (2012, 2013) juga menyatakan bahwa pemberian LbF213 pada subjek manusia dapat meningkatkan kenyamanan buang air besar sehingga berpotensi untuk mencegah konstipasi. LbF213 memiliki potensi yang baik untuk kesehatan dan dapat diaplikasikan ke dalam minuman sari buah menjadi minuman sari buah terfermentasi.

Proses fermentasi dipengaruhi oleh beberapa faktor antara lain suhu, $\mathrm{pH}$ awal fermentasi, inokulum, substrat dan kandungan nutrisi medium (Hidayat et al., 2006). Salah satu faktor yang mempengaruhi pertumbuhan mikroba adalah nutrisi media sebagai sumber energi seperti gula. Gula atau sukrosa merupakan disakarida yang dapat dirombak menjadi glukosa dan fruktosa oleh BAL sebagai sumber energi selama fermentasi sehingga menghasilkan metabolit berupa asam laktat, etanol, dan $\mathrm{CO}_{2}$ (Oberman and Libudzisz, 1998). Konsentrasi sukrosa yang ditambahkan dalam pembuatan minuman probiotik harus dalam jumlah yang tepat, hal ini untuk menunjang pertumbuhan BAL sehingga memperoleh jumlah bakteri yang mencukupi sesuai standar SNI susu fermentasi berperisa yaitu minimal 1 x $10^{6} \mathrm{cfu} / \mathrm{ml}$ (Anon., 2009).

Penelitian Harahap et al., (2018) tentang minuman probiotik sari tomat dan Elsaputra et al., (2016) tentang minuman probiotik kulit nanas menghasilkan karakteristik terbaik yaitu memiliki total BAL yang mencukupi sebesar 10,32 log $\mathrm{cfu} / \mathrm{ml}$ dan 7,08 $\log \mathrm{cfu} / \mathrm{ml}$, serta penilaian sensoris minuman probiotik kulit nanas yang disukai pada penambahan sukrosa $12 \%$. Penelitian lain tentang minuman probiotik jambu biji menghasilkan karakteristik terbaik yaitu total BAL yang mencukupi sebesar $1,5 \times 10^{10} \mathrm{cfu} / \mathrm{ml}$ dan evaluasi sensori tertinggi pada penambahan sukrosa 4\% (Nurainy et al., 2018). Jenis buah yang berbeda menghasilkan konsentrasi sukrosa 
terbaik yang berbeda pula sehingga pada minuman probiotik sari buah sirsak belum diketahui berapa persen sukrosa yang dapat menghasilkan karakteristrik minuman probiotik sari buah sirsak terfermentasi terbaik. Oleh karena itu perlu dilakukan penelitian mengenai konsentrasi sukrosa yang perlu ditambahkan untuk menghasilkan minuman sari buah sirsak terfermentasi dengan total BAL yang mencukupi dan nilai sensoris yang disukai.

\section{METODE PENELITIAN}

\section{Tempat dan Waktu}

Penelitian ini dilaksanakan di UPT. Laboratorium Terpadu Biosains dan Bioteknologi Universitas Udayana, Laboratorium Biokimia dan Nutrisi Fakultas Teknologi Pertanian, dan Laboratorium Rekayasa Proses dan Pengendalian Mutu Fakultas Teknologi Pertanian, Jl. Raya Kampus Udayana, Bukit Jimbaran. Pelaksanaan penelitian ini dilakukan pada bulan Juni hingga Agustus 2019.

\section{Bahan dan Alat}

Bahan yang digunakan dalam penelitian ini adalah isolat LbF213 (koleksi UPT Laboratorium Terpadu Biosains dan Bioteknologi Universitas Udayana), buah sirsak (dibeli di Pasar Kidul Bangli, Bali), gula pasir (Gulaku), air mineral, alkohol 96\%, de man, Rogosa, Sharpe Agar/MRSA (Oxoid), de man, Rogosa, Sharpe Broth/MRSB (Oxoid), akuades, $\mathrm{NaCl}$ 0,85\%, gliserol, kristal violet, larutan lugol, pewarna safranin, pereaksi anthrone (Merck), $\mathrm{H}_{2} \mathrm{SO}_{4}$ pekat, phenolphtalein $1 \%$, glukosa standar, larutan buffer pH 4 dan 7, larutan $\mathrm{H}_{2} \mathrm{O}_{2}$, indikator phenolphthalein (PP), $\mathrm{NaOH} 0,1 \mathrm{~N}, \mathrm{HCl} 4 \mathrm{~N}$, alumunium foil dan tisu.

Alat yang digunakan dalam penelitian ini adalah botol kaca, baskom, cawan petri (Petriq), tabung reaksi (Pyrex), jarum ose, inkubator, laminar air flow, spektrofotometer (evolution 201), pH-meter (martini instruments), timbangan analitik (Shimadzu AUX220), mikroskop (Olympus CX21FS1), pipet mikro (Finnpipette), pipet volume, labu ukur, erlenmeyer (pyrex), kertas saring, autoklaf, magnetic stirrer, waterbath (nvc thermologic), bunsen, blender, tip $100 \mu \mathrm{L}$, tip $1000 \mu \mathrm{L}$, vortex, gelas objek, freezer, pisau, talenan, kain saring, tabung mikrotube, sentrifugasi (clements GS150 centrifuge), gelas ukur, batang bengkok, kulkas, dan labu ukur.

\section{Pelaksanaan Penelitian}

\section{Penyegaran dan Konfirmasi Isolat}

Bakteri LbF213 dilakukan penyegaran dengan cara diambil $100 \mu L$ stok isolat yang disimpan dalam gliserol $30 \%$ pada suhu $-200^{\circ} \mathrm{C}$ dan diinokulasi pada $5 \mathrm{ml}$ media MRS Broth, lalu diinkubasi selama 24 jam dengan suhu $37^{\circ} \mathrm{C}$.

Setelah penyegaran, dilakukan konfirmasi isolat melalui uji katalase, pewarnaan gram dan uji gas. Uji katalase dilakukan dengan dibuat tetesan isolat pada gelas objek, kemudian ditetesi dengan dua tetes larutan $\mathrm{H}_{2} \mathrm{O}_{2}$, dan diamati gelembung yang timbul. Hasil positif ditunjukkan oleh timbulnya gelembung udara $\left(\mathrm{O}_{2}\right)$ yang dihasilkan dari degradasi $\mathrm{H}_{2} \mathrm{O}_{2}$ oleh enzim-enzim katalase (Suryani et al., 2010).

Pewarnaan gram dilakukan dengan meneteskan isolat pada gelas objek kemudian difiksasi di atas bunsen dan diwarnai dengan 
kristal violet selama 1 menit, kemudian ditetesi dengan larutan lugol selama 1 menit. Selanjutnya gelas objek ditetesi alkohol selama 1 menit dan terakhir diwarnai dengan pewarna safranin selama 5 detik. Sel bakteri yang telah diwarnai, dikeringkan dan diamati dibawah mikroskop (Suryani et al., 2010). Hasil positif ditunjukan oleh warna ungu yang berarti bahwa bakteri ini termasuk gram positif, hal ini dikarenakan bakteri tersebut memiliki kandungan lipid yang rendah, sehingga dinding sel bakteri akan lebih mudah terdehidrasi akibat perlakuan dengan alkohol yang menyebabkan ukuran pori-pori sel menjadi lebih kecil dan daya permeabilitasnya berkurang sehingga zat warna kristal violet yang merupakan zat warna utama tidak dapat keluar dari sel (Pelczar dan Chan, 1986).

Uji gas dilakukan dengan metode hot loop, dengan cara memasukkan jarum ose panas ke dalam suspensi biakan BAL. Hasil positif ditandai oleh terbentuknya gas $\mathrm{CO}_{2}$ dari hasil metabolisme glukosa (Suryani et al., 2010).

\section{Pembuatan Sari Buah}

Pembuatan sari buah sirsak dilakukan dengan proses sortasi terlebih dahulu. Buah sirsak yang dipakai pada penelitian ini adalah buah yang sudah masak. Buah dipotong menjadi 4 bagian terlebih dahulu lalu dikupas dan dipisahkan kulit serta bijinya. Buah ditambahkan air dengan perbandingan buah dan air 1:2. Tahap berikutnya buah dihancurkan dengan menggunakan blender. Selanjutnya dilakukan penyaringan pada sari buah dengan menggunakan 2 lapis kain saring, sehingga dihasilkan sari buah tanpa ampas (Diniyah et al., 2013).

\section{Pembuatan Starter Sari Buah}

Proses pembuatan starter diawali dengan mempersiapkan substrat berupa sari buah sirsak. Sebanyak $100 \mathrm{ml}$ sari buah ditambahkan gula sebesar $5 \%$, lalu dipasteurisasi dengan suhu $80^{\circ} \mathrm{C}$ selama 4,5 menit dengan menggunakan waterbath, lalu sari buah didinginkan hingga mencapai suhu $37^{\circ} \mathrm{C}$.

Proses selanjutnya diambil sebanyak $100 \mu \mathrm{l}$ stok kultur LbF213 dalam gliserol dan dimasukkan ke dalam $5 \mathrm{ml}$ media MRSB, lalu diinkubasi selama 24 jam pada suhu $37^{\circ} \mathrm{C}$. Setelah inkubasi, media tersebut diamati, hasil positif ditunjukkan dengan kekeruhan pada media, tabung reaksi tersebut kemudian divortex dan diambil sebanyak $1 \mathrm{ml}$, kemudian dipindahkan ke dalam tabung mikrotube untuk disentrifugasi pada kecepatan 5000 rpm selama 10 menit. Setelah disentrifugasi, akan terbentuk endapan kultur mikroba pada dasar tabung mikrotube. MRSB di atas endapan kultur tersebut dibuang, sedangkan sel yang tertinggal dicuci sebanyak 3 kali. Pencucian sel dilakukan dengan cara menambahkan larutan saline ke dalam tabung mikrotube berisi endapan kultur LbF213 lalu divortex, selanjutnya mikrotube disentrifugasi pada kecepatan 5000 rpm selama 10 menit, dan membuang supernatan yang terbentuk setelah proses sentrifugasi. Larutan saline sisa dari pencucian terakhir dibuang. Tahap berikutnya diambil sebanyak $1 \mathrm{ml}$ sari buah yang telah dibuat sebelumnya dan dimasukkan ke dalam tabung mikrotube. Tabung mikrotube tersebut divortex dan kultur dalam mikrotube dimasukkan ke dalam sari buah hingga mencapai volume $100 \mathrm{ml}$ 
kemudian dikocok. Sari buah tersebut kemudian difermentasi selama 24 jam pada suhu $37^{\circ} \mathrm{C}$ (Ding dan Shah, 2008).

\section{Pembuatan Sari Buah Sirsak Probiotik}

Sari buah sirsak yang dihasilkan dimasukan ke dalam jar sebanyak $90 \mathrm{ml}$. Sari buah sirsak ditambahkan sukrosa sesuai dengan perlakuan. Tahap berikutnya sari buah dipasteurisasi dengan suhu $80^{\circ} \mathrm{C}$ selama 4,5 menit dengan menggunakan waterbath. Proses ini bertujuan untuk menghentikan aktivitas mikroba maupun enzimatik pada sari buah. Didinginkan sari buah hingga mencapai suhu $37^{\circ} \mathrm{C}$. Setelah itu dimasukkan starter sebanyak $10 \%$ ke dalam jar yang berisi sari buah sesuai dengan masingmasing perlakuan, kemudian dikocok. Difermentasi sari buah selama 24 jam pada suhu $37^{\circ} \mathrm{C}$ (Diniyah et al., 2013).

\section{Rancangan Penelitian dan Analisis Data}

Penelitian ini menggunakan Rancangan Acak Kelompok (RAK) dengan perlakuan penambahan konsentrasi sukrosa yang terdiri dari 5 taraf perlakuan yaitu S0 (sukrosa 0\%), S3 (sukrosa 3\%), S6 (sukrosa 6\%), S9 (sukrosa 9\%), dan S12 (sukrosa 12\%). Masing-masing perlakuan diulang sebanyak 3 kali sehingga diperoleh 15 unit percobaan. Data total BAL dianalisis secara deskriptif dan data lainnya dianalisis dengan sidik ragam, apabila terdapat pengaruh antara perlakuan dilanjutkan dengan Uji Duncan (Gomez dan Gomez, 1995).

\section{Parameter yang Diamati}

Parameter yang diamati adalah total BAL dengan metode hitungan cawan (Fardiaz, 1992), total gula dengan metode Anthrone (Andarwulan et al., 2011), total asam dengan metode titrasi netralisasi (Sudarmadji et al., 1997), pH dengan pH meter (AOAC, 1995), dan evaluasi sensoris meliputi pengujian nilai kesukaan terhadap warna, aroma, rasa, dan penerimaan secara keseluruhan, sedangkan uji skoring dilakukan terhadap rasa asam dan manis (Soekarto, 1985).

\section{HASIL DAN PEMBAHASAN}

Hasil analisis total BAL, total gula, total asam, dan $\mathrm{pH}$ minuman sari buah sirsak terfermentasi dapat dilihat pada Tabel 1.

\section{Total BAL}

Nilai rata-rata total BAL minuman sari buah sirsak terfermentasi berkisar antara $1,27 \times 10^{10}$ cfu/ml sampai $7,33 \times 10^{10} \mathrm{cfu} / \mathrm{ml}$. Nilai total BAL sari buah sirsak sebelum difermentasi yaitu $1,32 \mathrm{x}$ $10^{7} \mathrm{cfu} / \mathrm{ml}$ dan terjadi peningkatan selama proses fermentasi. Tabel 1 menunjukkan peningkatan total BAL pada perlakuan konsentrasi sukrosa $0 \%$ sampai dengan $3 \%$ yaitu dari $2,08 \times 10^{10} \mathrm{cfu} / \mathrm{ml}$ menjadi $7,33 \times 10^{10} \mathrm{cfu} / \mathrm{ml}$, dan semakin menurun hingga konsentrasi sukrosa $12 \%$ yaitu menjadi $1,90 \times 10^{10} \mathrm{cfu} / \mathrm{ml}$. Peningkatan total BAL pada perlakuan $0 \%$ ke 3\% dikarenakan gula sederhana yang terdapat pada sari buah sirsak maupun sukrosa yang ditambahkan dapat dimanfaatkan secara optimal oleh BAL selama proses fermentasi. Penurunan total BAL pada perlakuan konsentrasi sukrosa 6\% sampai dengan 12\% disebabkan karena peningkatan jumlah sukrosa yang ditambahkan dapat merubah lingkungan pertumbuhan bakteri. 
Tabel 1. Nilai rata-rata total BAL, total gula, total asam, dan $\mathrm{pH}$ minuman sari buah sirsak terfermentasi

\begin{tabular}{ccccc}
\hline $\begin{array}{c}\text { Konsentrasi } \\
\text { Sukrosa }\end{array}$ & $\begin{array}{c}\text { Total BAL } \\
(\text { Log cfu/ml })\end{array}$ & Total Gula $(\%)$ & Total Asam $(\%)$ & $\mathrm{pH}$ \\
\hline $0 \%$ & $2,08 \times 10^{10}$ & $5,00 \pm 0,42 \mathrm{~d}$ & $1,44 \pm 0,42 \mathrm{a}$ & $3,84 \pm 0,05 \mathrm{a}$ \\
$3 \%$ & $7,33 \times 10^{10}$ & $9,21 \pm 2,70 \mathrm{c}$ & $1,57 \pm 0,48 \mathrm{a}$ & $3,83 \pm 0,06 \mathrm{a}$ \\
$6 \%$ & $1,27 \times 10^{10}$ & $12,91 \pm 3,16 \mathrm{~b}$ & $1,57 \pm 0,48 \mathrm{a}$ & $3,83 \pm 0,07 \mathrm{a}$ \\
$9 \%$ & $1,28 \times 10^{10}$ & $15,19 \pm 2,57 \mathrm{~b}$ & $1,57 \pm 0,48 \mathrm{a}$ & $3,83 \pm 0,09 \mathrm{a}$ \\
$12 \%$ & $1,90 \times 10^{10}$ & $17,96 \pm 2,02 \mathrm{a}$ & $1,44 \pm 0,54 \mathrm{a}$ & $3,83 \pm 0,08 \mathrm{a}$ \\
\hline
\end{tabular}

Keterangan: Huruf yang sama di belakang nilai rata-rata pada kolom yang sama menunjukkan berbeda tidak nyata.

Tingginya konsentrasi gula pada minuman sari buah sirsak terfermentasi merubah kondisi lingkungan menjadi hipertonik sehingga cairan dalam sel bakteri mengalir keluar yang mengakibatkan dehidrasi dan pengkerutan sel bakteri (plasmolisis). Tamime et al., (2006) menyatakan bahwa konsentrasi gula yang terlalu tinggi menyebabkan sel BAL akan mengalami lisis karena adanya perbedaan tekanan osmotik. Penurunan total BAL akibat tingginya konsentrasi sukrosa juga terjadi pada penelitian minuman probiotik sari buah jeruk siam kintamani dengan perlakuan konsentrasi sukrosa 5\% menurun pada konsentrasi $7,5 \%$ yaitu dari $1,1 \times 10^{9} \mathrm{cfu} / \mathrm{ml}$ menjadi 7,5 x $10^{8} \mathrm{cfu} / \mathrm{ml}$ (Mudamakin, 2016). Jumlah total BAL minuman sari buah sirsak terfermentasi semua perlakuan telah memenuhi standar SNI 7552:2009 tentang syarat minuman susu fermentasi berperisa yaitu minimal total BAL sebesar $10^{6} \mathrm{cfu} / \mathrm{ml}$.

\section{Total Gula}

Hasil sidik ragam menunjukkan bahwa perlakuan konsentrasi sukrosa berpengaruh nyata $(\mathrm{P}<0,05)$ terhadap total gula dari minuman sari buah sirsak terfermentasi. Nilai rata-rata total gula minuman sari buah sirsak terfermentasi berkisar antara $5,00 \%$ sampai $17,96 \%$. Nilai total gula terendah terdapat pada perlakuan konsentrasi sukrosa $0 \%$, sedangkan nilai total gula tertinggi terdapat pada perlakuan sukrosa $12 \%$.

Tabel 1 menunjukkan total gula dengan perlakuan sukrosa $0 \%$ semakin meningkat hingga konsentrasi sukrosa $12 \%$ yaitu dari 5,0\% menjadi 17,96\%. Hal ini disebabkan semakin tinggi konsentrasi sukrosa yang ditambahkan pada minuman sari buah sirsak terfermentasi maka total gula yang dihasilkan juga semakin tinggi. Nilai total gula sari buah sirsak sebelum difermentasi yaitu sebesar 12,41\%. Peningkatan total BAL diikuti dengan penurunan total gula, hal ini menandakan bahwa selama fermentasi berlangsung BAL mengkonsumsi gula untuk pertumbuhannya. Selama persediaan gula sederhana yang terkandung dalam sari buah sirsak masih mencukupi, sukrosa (disakarida) yang ditambahkan tidak semua dipecah menjadi gula sederhana dan diubah menjadi asam laktat saat proses fermentasi. Gula sisa yang terbentuk akan 
dihitung sebagai total gula, sehingga glukosa dan fruktosa yang terakumulasi tinggi menyebabkan total gula semakin meningkat (Sintasari et al., 2014).

\section{Total Asam}

Hasil sidik ragam menunjukkan bahwa penambahan sukrosa berpengaruh tidak nyata $(\mathrm{P}>0,05)$ terhadap total asam dari minuman sari buah sirsak terfermentasi. Nilai rata-rata total asam minuman sari buah sirsak terfermentasi berkisar antara $1,44 \%$ sampai $1,57 \%$.

Tabel 1 menunjukkan perubahan nilai total asam berbeda tidak nyata, hal ini berkaitan dengan proses metabolisme BAL. Selama fermentasi berlangsung, BAL melakukan proses metabolisme yang menghasilkan asam laktat yang akan terukur sebagai total asam (Sintasari et al., 2014). Bakteri LbF213 merupakan bakteri jenis heterofermentatif sehingga tidak hanya menghasilkan asam laktat, namun dihasilkan juga etanol dan $\mathrm{CO}_{2}$ yang diduga menyebabkan total asam yang dihasilkan tidak berbeda signifikan. Hasil menunjukkan semakin tinggi konsentrasi sukrosa yang ditambahkan pada minuman sari buah sirsak terfermentasi menghasilkan total BAL yang relatif sama, sehingga hal ini mengakibatkan asam laktat yang dihasilkan juga berbeda tidak nyata.

\section{Derajat Keasaman (pH)}

Hasil sidik ragam menunjukkan bahwa penambahan sukrosa berpengaruh tidak nyata $(\mathrm{P}>0,05)$ terhadap $\mathrm{pH}$ dari minuman sari buah sirsak terfermentasi. Nilai rata-rata $\mathrm{pH}$ minuman sari buah sirsak terfermentasi berkisar antara 3,84 sampai 3,83 .
Tabel 1 menunjukan perlakuan sukrosa tidak mempengaruhi $\mathrm{pH}$ dari minuman sari buah sirsak terfermentasi. Nilai $\mathrm{pH}$ sari buah sirsak sebelum difermentasi yaitu sebesar 3,86 dan mengalami penurunan menjadi $3,84-3,83$. Hal ini berkaitan dengan total asam laktat yang dihasilkan selama proses fermentasi. Winarno dan Fernandes (2007) menyatakan BAL pada umumnya merombak substrat berupa karbohidrat untuk menghasilkan sejumlah besar asam laktat. Asam laktat yang dihasilkan dari metabolisme karbohidrat dapat menurunkan nilai $\mathrm{pH}$ lingkungan pertumbuhannya dan menimbulkan rasa asam. Selama proses fermentasi, BAL akan menghasilkan asam laktat sehingga semakin banyak asam laktat yang dihasilkan maka $\mathrm{pH}$ cenderung semakin turun walaupun tidak nyata. Hasil penelitian menunjukan seiring dengan konsentrasi sukrosa yang ditambahkan pada minuman sari buah sirsak terfermentasi menghasilkan total BAL yang relatif sama, sehingga total asam yang dihasilkan berbeda tidak nyata. Hal ini pula yang mengakibatkan $\mathrm{pH}$ dari minuman sari buah sirsak terfermentasi berbeda tidak nyata.

\section{Evaluasi Sensoris (Uji Hedonik dan Uji Skoring)}

Uji sensoris minuman sari buah sirsak terfermentasi meliputi uji hedonik terhadap warna, aroma, rasa, dan penerimaan keseluruhan, sedangkan uji skoring dilakukan terhadap rasa asam dan rasa manis. Nilai rata-rata uji hedonik terhadap warna, aroma, rasa dan penerimaan keseluruhan serta nilai rata-rata uji skoring 
terhadap rasa asam dan rasa manis dapat dilihat pada Tabel 2.

\section{Warna}

Hasil sidik ragam menunjukkan bahwa perlakuan konsentrasi sukrosa berpengaruh tidak nyata $(\mathrm{P}>0,05)$ terhadap warna dari minuman sari buah sirsak terfermentasi. Tabel 2 menunjukkan hasil uji hedonik oleh panelis terhadap warna minuman sari buah sirsak terfermentasi adalah suka.

Tabel 2. Nilai rata-rata evaluasi sensoris minuman sari buah sirsak terfermentasi

\begin{tabular}{ccccccc}
\hline $\begin{array}{c}\text { Konsentrasi } \\
\text { Sukrosa }\end{array}$ & $\begin{array}{c}\text { Warna } \\
\text { (hedonik) }\end{array}$ & $\begin{array}{c}\text { Aroma } \\
\text { (hedonik) }\end{array}$ & $\begin{array}{c}\text { Rasa } \\
\text { (hedonik) }\end{array}$ & $\begin{array}{c}\text { Rasa Asam } \\
\text { (skor) }\end{array}$ & $\begin{array}{c}\text { Rasa Manis } \\
\text { (skor) }\end{array}$ & $\begin{array}{c}\text { Penerimaan } \\
\text { Keseluruhan } \\
\text { (hedonik) }\end{array}$ \\
\hline $0 \%$ & $5,67 \mathrm{a}$ & $5,67 \mathrm{a}$ & $3,93 \mathrm{c}$ & $3,20 \mathrm{a}$ & $3,93 \mathrm{a}$ & $4,67 \mathrm{c}$ \\
$3 \%$ & $5,53 \mathrm{a}$ & $5,53 \mathrm{a}$ & $4,93 \mathrm{~b}$ & $2,47 \mathrm{~b}$ & $3,33 \mathrm{~b}$ & $5,27 \mathrm{~b}$ \\
$6 \%$ & $5,47 \mathrm{a}$ & $5,47 \mathrm{a}$ & $5,67 \mathrm{a}$ & $1,93 \mathrm{c}$ & $2,67 \mathrm{c}$ & $5,60 \mathrm{ab}$ \\
$9 \%$ & $5,47 \mathrm{a}$ & $5,73 \mathrm{a}$ & $5,73 \mathrm{a}$ & $1,73 \mathrm{~cd}$ & $2,07 \mathrm{~d}$ & $5,67 \mathrm{ab}$ \\
$12 \%$ & $5,40 \mathrm{a}$ & $5,40 \mathrm{a}$ & $5,87 \mathrm{a}$ & $1,47 \mathrm{~d}$ & $1,93 \mathrm{~d}$ & $5,87 \mathrm{a}$
\end{tabular}

Keterangan: Huruf yang sama di belakang nilai rata-rata pada kolom yang sama menunjukkan perlakuan berbeda tidak nyata.

Kriteria hedonik $\quad: 7=$ sangat suka, $6=$ suka, $5=$ agak suka, $4=$ biasa,

$3=$ agak tidak suka, $2=$ tidak suka, $1=$ sangat tidak suka.

Kriteria skor rasa asam : $1=$ tidak asam, $2=$ agak asam, $3=$ asam, $4=$ sangat asam.

Kriteria skor rasa manis : $1=$ sangat manis, $2=$ manis, $3=$ agak manis, $4=$ tidak manis.

\section{Aroma}

Hasil sidik ragam menunjukkan bahwa perlakuan konsentrasi sukrosa berpengaruh tidak nyata $(\mathrm{P}>0,05)$ terhadap aroma dari minuman sari buah sirsak terfermentasi. Tabel 2 menunjukann hasil uji hedonik oleh panelis terhadap aroma minuman sari buah sirsak terfermentasi adalah suka.

\section{Rasa}

Hasil sidik ragam menunjukkan bahwa perlakuan konsentrasi sukrosa berpengaruh nyata $(\mathrm{P}<0,05)$ terhadap kesukaan rasa, skor rasa asam dan skor rasa manis dari minuman sari buah sirsak terfermentasi. Berdasarkan hasil uji hedonik oleh panelis terhadap rasa minuman sari buah sirsak terfermentasi, diperoleh nilai berkisar dari 3,93 (biasa) hingga 5,87 (suka), sedangkan berdasarkan uji skoring terhadap rasa asam diperoleh nilai berkisar dari 1,47 (tidak asam) hingga 3,20 (asam) dan uji skoring terhadap rasa manis diperoleh nilai berkisar dari 1,93 (manis) hingga 3,93 (tidak manis). Nilai kesukaan rasa terendah terdapat pada perlakuan sukrosa $0 \%$ dengan kriteria biasa, sedangkan nilai kesukaan rasa tertinggi terdapat pada perlakuan sukrosa $12 \%$ dengan kriteria suka dan tidak berbeda nyata dengan perlakuan sukrosa $6 \%$ dan $9 \%$.

Berdasarkan hasil uji hedonik dan uji skoring, konsentrasi sukrosa $0 \%$ memiliki kriteria rasa asam dan tidak manis, konsentrasi sukrosa 3\% memiliki kriteria rasa agak asam dan agak 
manis, konsentrasi sukrosa 6\% memiliki kriteria rasa agak asam dan agak manis, konsentrasi sukrosa 9\% memiliki kriteria rasa agak asam dan manis, konsentrasi sukrosa $12 \%$ memiliki kriteria rasa tidak asam dan manis. Peningkatan konsentrasi sukrosa yang ditambahkan berbanding lurus dengan peningkatan rasa manis. Hal ini dikarenakan sukrosa merupakan salah satu komponen pembentuk rasa manis pada produk pangan. Semakin tinggi penambahan sukrosa maka rasa asam dari minuman sari buah sirsak terfermentasi semakin berkurang. Hal ini dikarenakan tingkat kemanisan yang dimiliki sukrosa cukup tinggi dan lebih mendominasi seiring dengan bertambahnya konsentrasi sukrosa, sehingga mengurangi rasa asam dari minuman sari buah sirsak terfermentasi. Semakin tinggi sukrosa yang ditambahkan tingkat kesukaan panelis terhadap rasa dari minuman sari buah sirsak terfermentasi cenderung semakin meningkat.

\section{Penerimaan Keseluruhan}

Hasil sidik ragam menunjukkan bahwa penambahan sukrosa berpengaruh nyata $(\mathrm{P}<0,05)$ terhadap penerimaan keseluruhan dari minuman sari buah sirsak terfermentasi. Berdasarkan hasil uji hedonik oleh panelis terhadap penerimaan keseluruhan minuman sari buah sirsak terfermentasi berkisar antara 4,67 (agak suka) sampai 5,87 (suka). Nilai penerimaan keseluruhan terendah terdapat pada perlakuan sukrosa $0 \%$ dengan kriteria agak suka, sedangkan nilai penerimaan keseluruhan tertinggi terdapat pada perlakuan sukrosa $12 \%$ dengan kriteria suka. Semakin tinggi sukrosa yang ditambahkan tingkat kesukaan panelis cenderung semakin meningkat sampai dengan konsentrasi sukrosa $6 \%$ dan memiliki kriteria penilaian yang berbeda tidak nyata dengan konsentrasi sukrosa $9 \%$ dan $12 \%$ yaitu suka.

\section{KESIMPULAN DAN SARAN}

\section{Kesimpulan}

Berdasarkan hasil penelitian dapat disimpulkan hal-hal sebagai berikut:

1. Perlakuan sukrosa pada minuman sari buah sirsak terfermentasi berpengaruh nyata terhadap total gula, rasa (hedonik), rasa asam dan rasa manis (skoring), serta penerimaan keseluruhan, tetapi tidak berpengaruh nyata terhadap total BAL, total asam, $\mathrm{pH}$, warna, dan aroma.

2. Penambahan sukrosa $6 \%$ menghasilkan minuman sari buah sirsak terfermentasi terbaik dengan karakteristik total BAL $1,27 \times 10^{10}$ $\mathrm{cfu} / \mathrm{ml}$, total gula $12,91 \%$, total asam $1,57 \%$, $\mathrm{pH} 3,83$, warna dan aroma agak disukai, rasa agak asam dan agak manis yang disukai, dan penerimaan keseluruhan disukai.

\section{Saran}

Berdasarkan hasil penelitian, disarankan menggunakan konsentrasi sukrosa $6 \%$ dalam pembuatan minuman sari buah sirsak terfermentasi untuk memperoleh karakteristik terbaik. Perlu dilakukan penelitian lebih lanjut mengenai viabilitas LbF213 pada sari buah sirsak terfermentasi selama penyimpanan dingin. 


\section{DAFTAR PUSTAKA}

Andarwulan, N., F. Kusnandar, dan D. Herawati. 2011. Analisis Pangan. Dian Rakyat, Jakarta.

Anonimous. 2009. SNI-7522-2009 tentang Minuman Susu Fermentasi Berperisa. Badan Standardisasi Nasional, Jakarta.

AOAC. 1995. Official Methods of Analysis. 16th Edition. Association of Official Analytical Chemists, Washington DC.

Ding, W.K. dan N.P. Shah. 2008. Survival of free and microencapsulated probiotics bacteria in orange and apple juices. Int Food Res J. 15:219-232.

Diniyah, N., A. Subagio, dan M. Fauzi. 2013. Produksi minuman fungsional sirsak (Anona muricata linn) dengan fermentasi bakteri asam laktat. Jurnal Teknotan 2(7):1007-1012.

Elsaputra, U. Pato, dan Rahmayuni. 2016. Pembuatan minuman probiotik berbasis kulit nanas (Ananas comosus L. merr.) menggunakan Lactobacillus casei subsp. casei R-68 yang diisolasi dari dadih. Jom Faperta 3(1).

Fardiaz, S. 1992. Mikrobiologi Pangan I. Gramedia Pustaka Utama, Jakarta.

Gomez, K.A. dan A.A. Gomez. 1995. Prosedur Statistik untuk Penelitian Pertanan. Edisi kedua. UI-Press, Jakarta.

Harahap, N.O., V.S. Johan, dan U. Pato. 2018. Pembuatan minuman fermentasi sari tomat dengan menggunakan Lactobacillus casei subsp. casei R-68. JOM UR 5(2):1-15.

Hidayat, N., M. Padaga, dan Suhartini S. 2006. Mikrobiologi Industri. Andi, Yogyakarta.

Mudamakin, A.E.L. 2016. Pengaruh Konsentrasi Gula dan Enkapsulasi terhadap Viabilitas Lactobacillus rhamnosus SKG34 dan Karakteristik Minuman Probiotik Sari Buah Jeruk Siam Kintamani (Citrus nobillis var. microcarpa). Skripsi. Tidak dipublikasikan. Fakultas Teknologi Pertanian UNUD, Jimbaran.
Nurainy, F., S. Rizal, S. Suharyono, dan E. Umami. 2018. Karakteristik minuman probiotik jambu biji (Psidium guajava) pada berbagai variasi penambahan sukrosa dan susu skim. Jurnal Aplikasi Teknologi Pangan (7)2.

Oberman, H. and Z. Libudzisz. 1998. Fermented milks. In : Microbiology of Fermented Foods. 2nd ed. (1):208-350. Edited by: B.J.B. Wood. Blackie Academic and Professional, London.

Pelczar, M.J. dan E.C.S. Chan. 1986. Penerjemah, Ratna Siri Hadioetomo dkk. Dasar-Dasar Mikrobiologi 1. Universitas Indonesia Press, Jakarta.

Rini, A.P. 2019. Viabilitas Lactobacillus sp F213 pada Berbagai Minuman Probiotik Sari Buah Selama Penyimpanan. Skripsi. Tidak dipublikasikan. Fakultas Teknologi Pertanian UNUD, Jimbaran.

Rizal, S., M. Erna, F. Nurainy, dan A.R. Tambunan. 2016. Karakteristik probiotik minuman fermentasi laktat sari buah nanas dengan variasi jenis bakteri asam laktat. Jurnal Kimia Terapan Indonesia 18(1):6371.

Sintasari, R.A., J. Kusnadi, dan D.W. Ningtyas. 2014. Pengaruh Penambahan Konsentrasi Susu Skim dan Sukrosa terhadap Karakterisik Minuman Probiotik Sari Beras Merah. J. Pangan dan Agroindustri. 2(3):6575 .

Soekarto, S.T. 1985. Penelitian Organoleptik Untuk Industri Pangan dan Hasil Pertanian. Bharata Karya Aksara, Jakarta.

Sudarmadji. S., B. Haryono, dan Suhardi. 1997. Prosedur Analisa untuk Bahan Makanan dan Pertanian. Liberty. Yogyakarta.

Sujaya, I N. 2010. Development of Probiotic for Diarrheagenic Pathogens. International Symposium on Bioscinece and Biotechnology. Udayana University, Bali.

Sujaya, I N., D.M. Sukrama, Y. Ramona, K.A. Nocianitri, T. Sone, dan K. Asano. 2012. Resistantce of Lactobacillus sp. F213 in human gastrointestinal tract as reveal by Polymerase Chain Reaction-Denaturing 
Gradient Gel Electrophoresis of fecal microbiome. (Laporan Penelitian Kerjasama Luar Negeri, Universitas Udayana).

Sujaya, I N, D.M. Sukrama, Y. Ramona, K.A. Nocianitri, T. Sone, dan K. Asano. 2013. Resistantce of Lactobacillus sp. F213 in human gastrointestinal tract as reveal by Polymerase Chain Reaction-Denaturing Gradient Gel Electrophoresis of fecal microbiome. (Laporan Penelitian Kerjasama Luar Negeri, Unud).

Suryani, Y., A.B. Oktavia, dan S. Umniyati. 2010. Isolasi dan karakterisasi bakteri asam laktat dari limbah kotoran ayam sebagai agensi probiotik dan enzim kolesterol reduktase. Biota. 12(3):177-185.

Tamime, A.Y., Nilsson, L.E., S. Lyck. 2006. Fermented milks. Oxford, Blackwell.

Winarno, F. G. dan Fernandez. 2007. Susu dan Produk Fermentasinya. MBrio Press. Bogor. 